\title{
A Syntactic Analysis on Sentences Found in the English Textbook for the Tenth Grade Students Entitled "Bahasa Inggris Kelas X" (2017 revised edition) Published by Ministry of Education and Culture Republic of Indonesia
}

\author{
Liana Mumrikoh', Eka Agustina², and Hastuti Retno Kuspiyah ${ }^{3}$ \\ Pendidikan Bahasa Inggris STKIP Nurul Huda Sukaraja \\ 1'Lianamumrikoh29@gmail.com \\ 2Ekaagustina@stkipnurulhuda.ac.id \\ 3retno@stkipnurulhuda.ac.id

\section{Abstract}

This study is an analysis of sentence structure by using a syntactic approach that portrayed in the tree diagram. This study focused only on the discussion covering the identification of types of sentence and sentence structure. It was found that there are 191 sentences from the six selected text in the textbook consisting of the simple sentence which has 53 sentences $(27,75 \%)$, the compound sentence has 79 sentences $(41,36 \%)$, the complex sentence has 33 sentences $(17,27 \%)$ and the compound-complex sentence has 26 sentences $(13,61 \%)$ from the total number of the data. The finding of the analysis shows that the English textbook has all types of sentences, based on both several clauses and their syntactic properties. A drawing tree diagram is a fundamental skill in the study of syntactic structure; it is a common practice to provide a visual representation of the internal structure of phrase and clause. Tree diagrams are a clear way of representing syntactic structure graphically.

Keywords: syntactic analysis, sentences, English textbook

\section{INTRODUCTION}

Language has an important role in society, Soeparno (2002:5) stated that there is no society without any language and there is no language without society. That's the reason why we need to master the language to keep communication with others. Many experts have discussed and explained their findings of human language.

A study that scientifically discusses human language is called linguistic. According to Finegan (2003:22), linguistics can be defined as the systematic inquiry into human language-into its structures and uses and the relationship between them, as well as into the development and acquisition of language. Furthermore, Chair (2007:15) tells that internal language structure is an object of micro linguistics that involves a system of sound, word formation, sentence structure, etc. Sentence structure is the main instrument in linguistic study.

Meanwhile, a sentence is a group of words that are tied together and convey an idea, event or description. Also, Miller (2002:76) stated that traditional definitions of sentence talk of a grammatical unit built up from the smaller unit. The smaller units (phrases and clauses) are linked to each other by various head modifier relations. Sentence themselves cannot be described as occurring in any particular slot in a piece of text. This definition implies that the sentence has a certain sort of unity, being grammatical complete, and has a degree of semantic independence which enables it to stand on its independent of context. As one of linguistics analysis, the syntax study is fundamental in linguistics and language study. Since, syntax studies have the rules that govern how words combined to form phrases, clauses, and sentences.

There are four different sentence types according to the number of clauses, namely; simple, compound, complex, compound-complex. Moreover, Aarts (2001:58) stated that within syntactic properties can classify sentences into four types, such as declarative sentence, interrogative 
sentence, imperative sentence, and explanative sentence. A declarative sentence is a sentence that emphasizes on the straightest forward. In the process of arranging a sentence, the object can be arranged with other elements, if it is needed at the end of the sentence. Then put the predicator which is followed by an indirect object, direct object or other elements, if it is needed at the end of the sentence. These sentences have the utilizing such as statement, interrogative for asking the question, imperative sentence for giving command, explanative sentence for giving any explanation or instruction.

Besides, Matthews (as cited in Christianto, 2018) stated that syntax terminology is derived from the term Syntaxes from the Ancient Greek which means 'arrangement' or 'string out together'. It refers to how the words are put together to build a phrase, how phrases are put together to build clauses or bigger phrases, and how clauses are put together to build sentences.

Meanwhile, the study of syntax can be applied in many subjects, one of them in the textbook. Teaching and learning activities between teachers and students will be detached from teaching material. Teaching materials are an important part of the implementation of teaching and learning activities in the classroom. Teaching materials must be made according to the requirements of the building. Furthermore, the Minister of Education (2008:6) argues that teaching materials are learning materials used to help students learning process. The textbook is one of the important elements in the teaching and learning process. Besides, Graves (2000:175) also stated that textbook is a book used as a standard source of information for a formal study of a subject and an instrument for teaching and learning.

A textbook is expected to truly have the quality of the content under the curriculum, from the standard content or from the manner of difficultness teaching material that mastered by the teacher and the students, as well as presented appropriately. The high quality of the coursebook can provide optimal results in the learning process. Furthermore, Riyanto (as cited in Hendrawanto and Mulyani, 2017) said that at least four criteria must be complete if a teaching material can be said to be good. Firstly, the scope of material or content under the curriculum. Second, the presentation of material meets the principles of learning. Third, language and good readability. Fourth, the format of the book or interesting graphics. It means that the language of the textbook is one important thing that should be focused on making good quality of the teaching material.

Then, based on the result of interviewing English teacher delegation from three subdistricts in East Oku regency, the writer was found: 1) Knowing the problem of the sentence in English textbook was used, 2) Ungrammatical of the sentence in the English textbook, 3) Misinterpretation the meaning of the content from the sentence in the English textbook.

From the explanations above, the writer interest to analyze about the syntactic on sentence structure in the textbook entitled "A Syntactic Analysis on Sentences Found in The English Textbook For the Tenth Grade Students Entitled "Bahasa Inggris Kelas X" (2017 revised edition) Published By Ministry of Education and Culture Republic of Indonesia".

\section{METHODOLOGY}

This research includes qualitative research that used descriptive method because the object of the study is a textbook. Based on Creswell (2010:34) said that qualitative research is the research that intended to pronounce symptoms holistically and contextually using data from background natural to make us a researcher as a key of the instrument.

The writer used descriptive research because the implementation includes the data, analysis, and interpretation of the meaning of the data obtained. Besides, Arikunto (2013:3) stated that "the descriptive research is the research to investigate the situations, conditions or the other things that mentioned, which the result that explained in the form of the research report". 
The object of this research is the English textbook entitled "Bahasa Inggris Kelas X" (2017 revised edition). It is a source of original data and the basis of the study. The primary source is taken from the English textbook entitled "Bahasa Inggris Kelas X" (2017 revised edition).

There were five steps that the writer used to collect the data. Firstly, the writer took an observation of the English textbook content whether the data were available in the textbook. The writer observes the covered texts in the textbook that could be classified on syntactic structure. Secondly, the writer searched and collected several theories that supported the reliability of data selection. The writer mainly collected the relevant theories from several published books, journals, and supported articles. Thirdly, the writer selected reliable data that could be classified into four kinds of the sentence, such as declarative sentence, imperative sentence, interrogative sentence, and exclamative sentence. The data that the writer took from the textbook was technically in the form of paragraphs. After collecting the data, fourthly, the writer analyzed the syntactic structure of the sentences. In the last step of the technique of the data collection, the writer classified the data in the table. The writer classified the data that analyzed later as a syntactic structure that was realized in the textbook itself.

Data analysis is the process of systematically searching and arranging the interview transcripts, field notes, and other materials that you accumulate to increase your understanding of them and to enable you to present what you have discovered to others (Bogdan (2001:145)). While based on Creswell (2012:236) states that analyzing qualitative data requires understanding how to make sense of text and images so that you can form an answer to your research questions. The technique for analyzing the data are used by the writer, as follow:

1) Read the English textbook entitled "Bahasa Inggris Kelas X" (2017 revised edition) selected the text to be analyzed.

2) Identifying and classifying the sentences based on the number of full predictions, such as simple sentence, compound sentence, complex sentence, and compound-complex sentence.

3) Identifying Types of sentences based on their syntactic properties.

4) Portraying selected sentences into a tree diagram.

5) Concluding the research report.

\section{RESULT AND DISCUSSION}

The result of syntactic analysis in the English textbook "Bahasa Inggris Kelas $X$ (2017 revised edition)" the writer found there are 191 sentences in the English textbook entitled "Bahasa Inggris Kelas X (2017 revised edition)", the content of the text consist of a simple sentence, compound sentence, complex sentence, and compound-complex sentence. The simple sentence that found from text 1 consists of 5 sentences, text 2 consists of 3 sentences, text 3 consists of 9 sentences, text 4 consists of 10 sentences, text 5 consists of 21 sentences, and text 6 consists of 5 sentences. The compound sentence from text 1 consists of 8 sentences, text 2 consists of 4 sentences, text 3 consists of 14 sentences, text 4 consists of 16 sentences, text 5 consists of 26 sentences, and text 6 consists of 11 sentences. The complex sentence from text 1 consists of 5 sentences, text 2 consists of 10 sentences, text 3 consists of 8 sentences, text 4 consists of 4 sentences, text 5 consists of 2 sentences, and text 6 consists of 4 sentences. The compound-complex sentences from text 1 consist of 7 sentences, text 2 consists of 1 sentence, text 3 do not have sentences, text 4 consists of 4 sentences, text 5 consists of 7 sentences, and text 6 consists of 7 sentences.

There were 191 sentences with percentage is $100 \%$ from the 6 texts in the textbook. It is consists of a simple sentence that has $27,75 \%$ or 53 sentences, the compound sentence has $41,36 \%$ or 79 sentences, the complex sentence has $17,27 \%$ or 33 sentences and the compound-complex sentence has $13,61 \%$ or 26 sentences from the total number of the data. Therefore, in the discussion, the writer displayed the tree diagram for syntactic analysis in the textbook.

1. Simple Sentence

There were 53 simple sentences found in text 1 to 6 in the textbook, the writer took 5 simple sentences because simple sentences have the same structure. The sentence structure of a 
A Syntactic Analysis on Sentences Found in the English Textbook for the Tenth Grade Students

Entitled "Bahasa Inggris Kelas X" (2017 revised edition) Published by Ministry of Education and

Culture Republic of Indonesia

Liana Mumrikoh', Eka Agustina ${ }^{2}$, and Hastuti Retno Kuspiyah ${ }^{3}$

simple sentence such as:

$\mathrm{S} \Longrightarrow \mathrm{NP}+\mathrm{VP}, \mathrm{VP} \rightarrow \mathrm{VP}+\mathrm{NP}, \mathrm{VP} \longrightarrow \mathrm{V}+\mathrm{NP}, \mathrm{VP} \rightarrow \mathrm{V}+\mathrm{AdVP}, \mathrm{VP} \rightarrow \mathrm{V}+\mathrm{PP}$

The structure above was indicating a simple sentence because it only has one sentence that consists of one noun phrase and one verb phrase. Furthermore, the tree diagram of simple sentences as follows:

He was just an amazing person. (page 111 line 34)

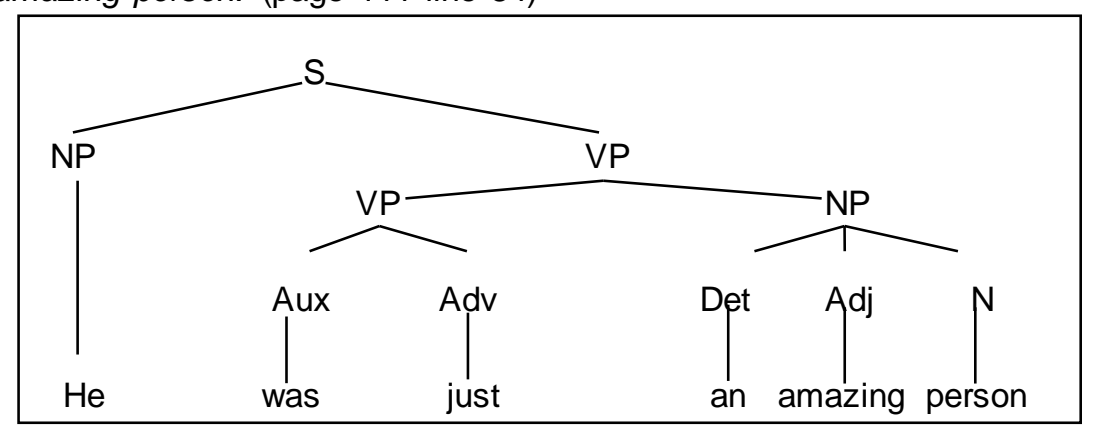

Chart 1. Tree diagram of a simple sentence

In this sentence structure portrayed in a tree, the diagram has the same subject, one verb phrase, and one noun phrase.

She was born in Lampang in 1848. (page 145 line 2)

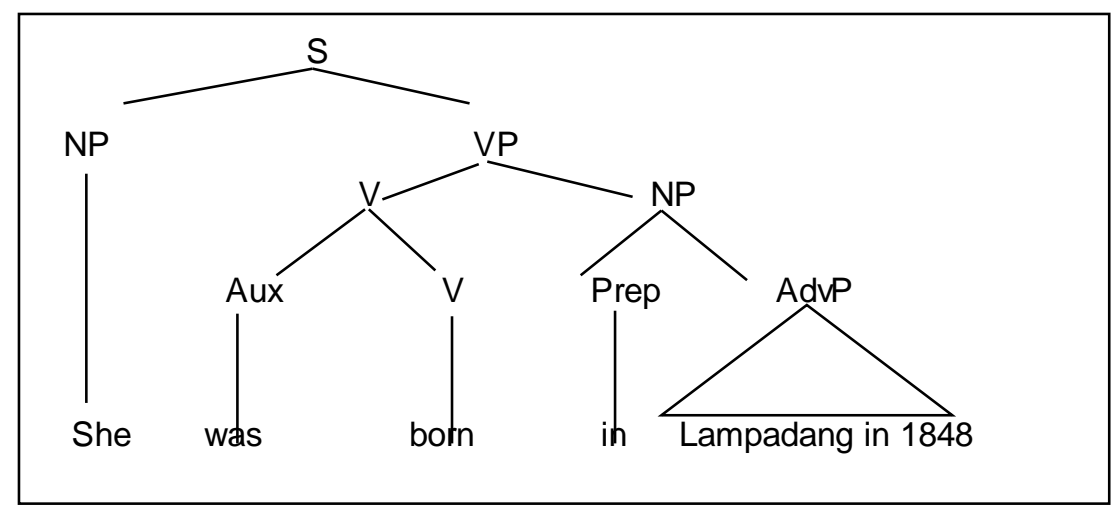

Chart 2. Tree diagram of a simple sentence

In this sentence structure portrayed in a tree, the diagram has one subject and one verb. In the sentence, there are two adverbs, but in a tree, the diagram has only portrayed in one adverb. 
42 | Channing: English Language Education and Literature Vol. 4 No. 2 October 2019 Halaman: 37-49

They were married in 1880. (page 146 line 28)

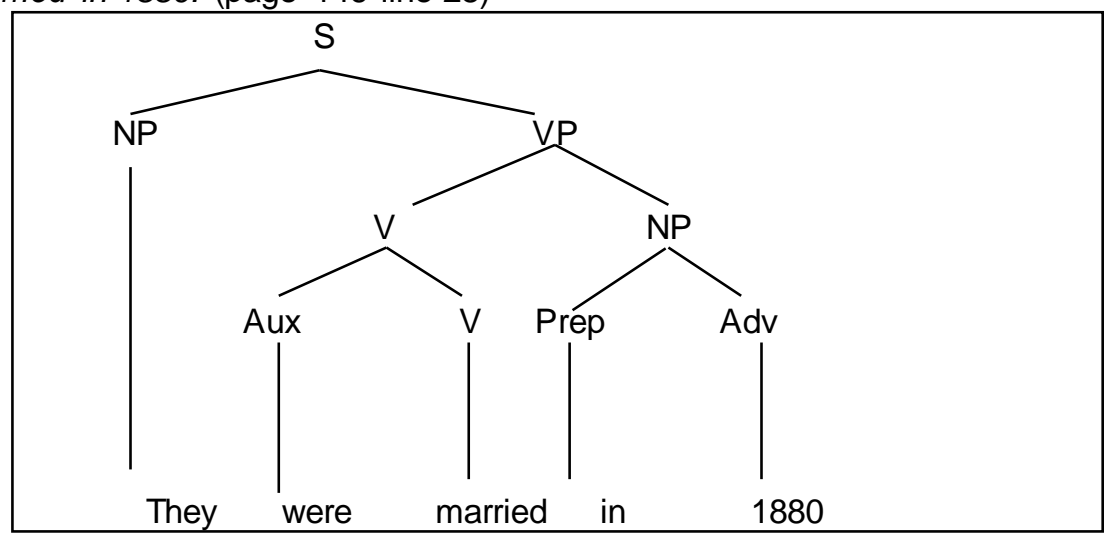

Chart 3. Tree diagram of a simple sentence

In this sentence structure portrayed in the tree, the diagram has one subject, one verb, and one adverb.

They lived happily ever after. (page 159 line 64)

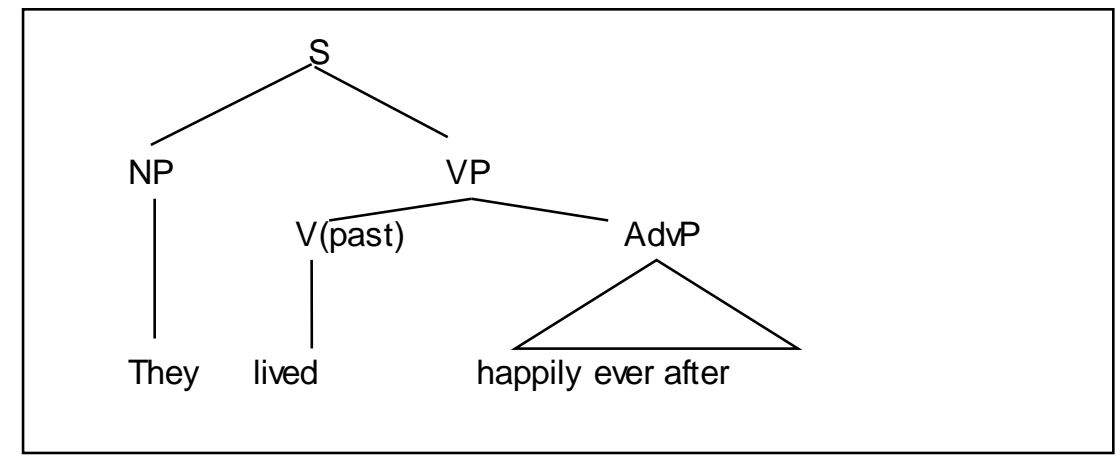

Chart 4. Tree diagram of a simple sentence

In this sentence structure portrayed in the tree, the diagram has one subject and one verb. In the sentence, there are three adverbs, but in a tree, a diagram showed one adverb because it has the same structure.

He left his mother alone. (page 172 line 9-10)

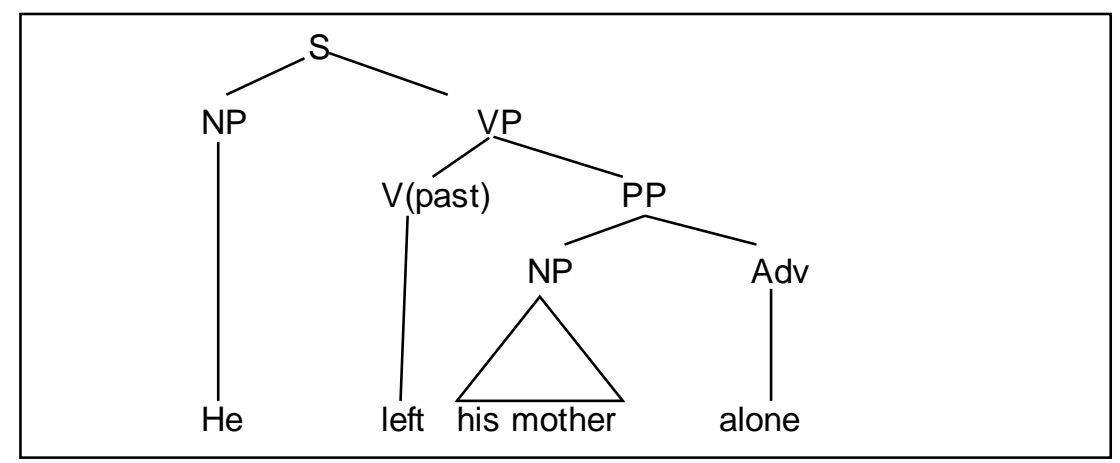

Chart 5. Tree diagram of a simple sentence

2. Compound Sentence

There are 79 sentences found in text 1 to 6 in the textbook, the writer took 5 compound sentences because some of the compound sentences have the same structure. The sentence structure of compound sentence such as: 
A Syntactic Analysis on Sentences Found in the English Textbook for the Tenth Grade Students

Entitled "Bahasa Inggris Kelas X" (2017 revised edition) Published by Ministry of Education and

Culture Republic of Indonesia

Liana Mumrikoh', Eka Agustina ${ }^{2}$, and Hastuti Retno Kuspiyah ${ }^{3}$

$\mathrm{S} \Rightarrow \mathrm{S}+$ conjunction $+\mathrm{S}, \mathrm{S} \Rightarrow \mathrm{S}+$ punctuation $+\mathrm{S}, \mathrm{S} \longrightarrow \mathrm{NP}+\mathrm{VP}, \mathrm{S} \longrightarrow \mathrm{VP}+\mathrm{AdVP}$,

$\mathrm{S} \rightarrow \mathrm{NP}+\mathrm{Aux}+\mathrm{V}, \mathrm{S} \rightarrow \mathrm{V}+\mathrm{NP}$

The structure above was indicating as a compound sentence because it has two sentences and connecting with conjunction or punctuation. Meanwhile, the tree diagram of compound sentences as follows:

I prepared my CDs and began to stand in the line. (page 111 line 27-28)

The compound sentence above consists of two independent clauses joined by the conjunction "and".

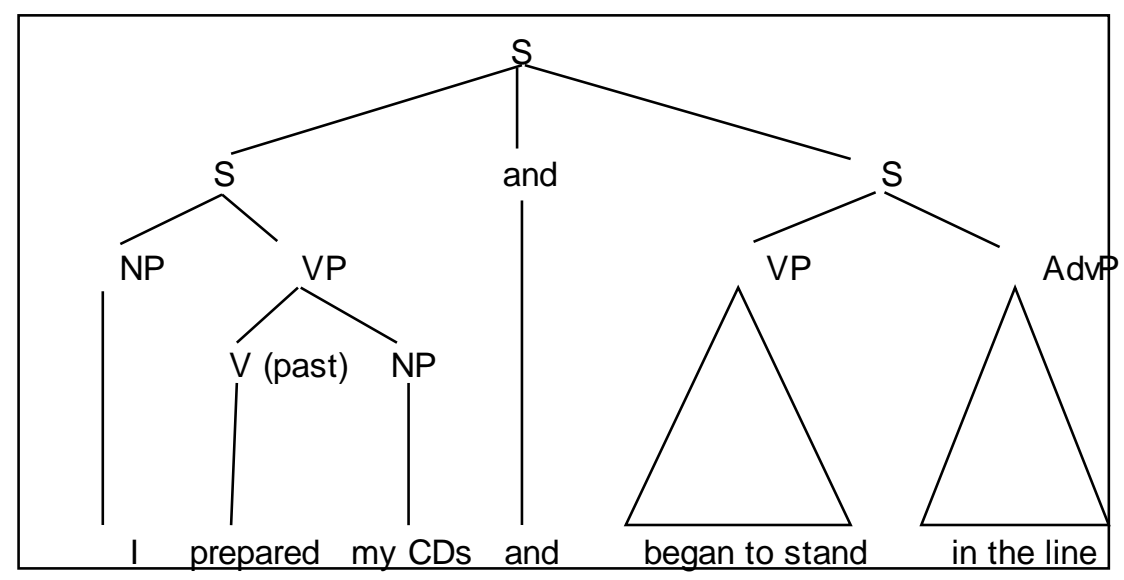

Chart 6. Tree diagram of a compound sentence

When I arrived at the table, I was speechless. (page 111 line 28)

The compound sentence above consists of two independent clauses joined by punctuation "comma".

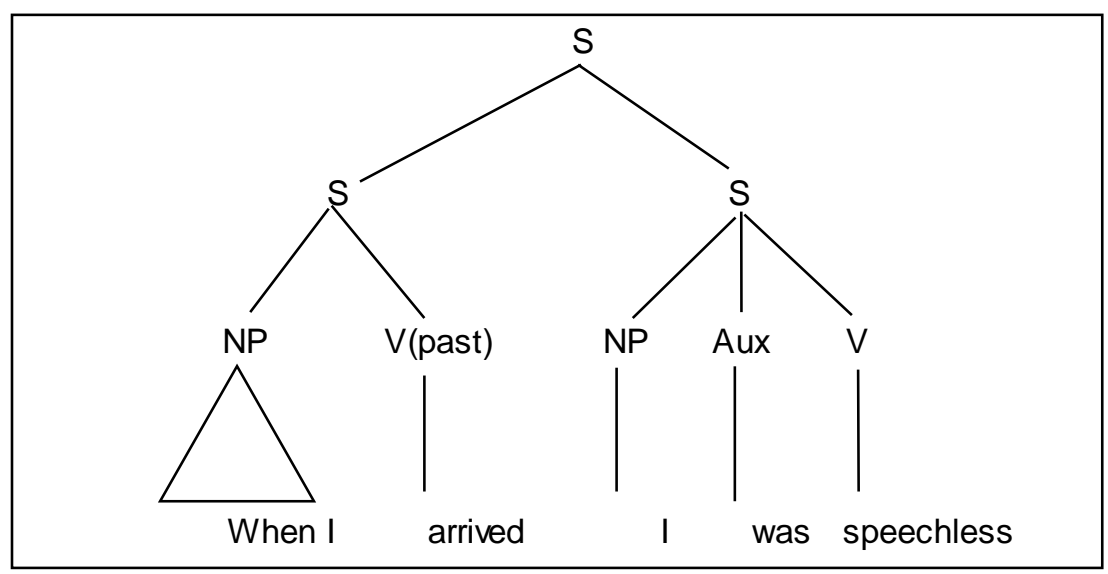

Chart 7. Tree diagram of a compound sentence

They raised Issumboshi with much care, but Issumboshi never grew bigger. (page 157 line 10)

The compound sentence above consists of two independent clauses joined by punctuation "comma" and "but". 


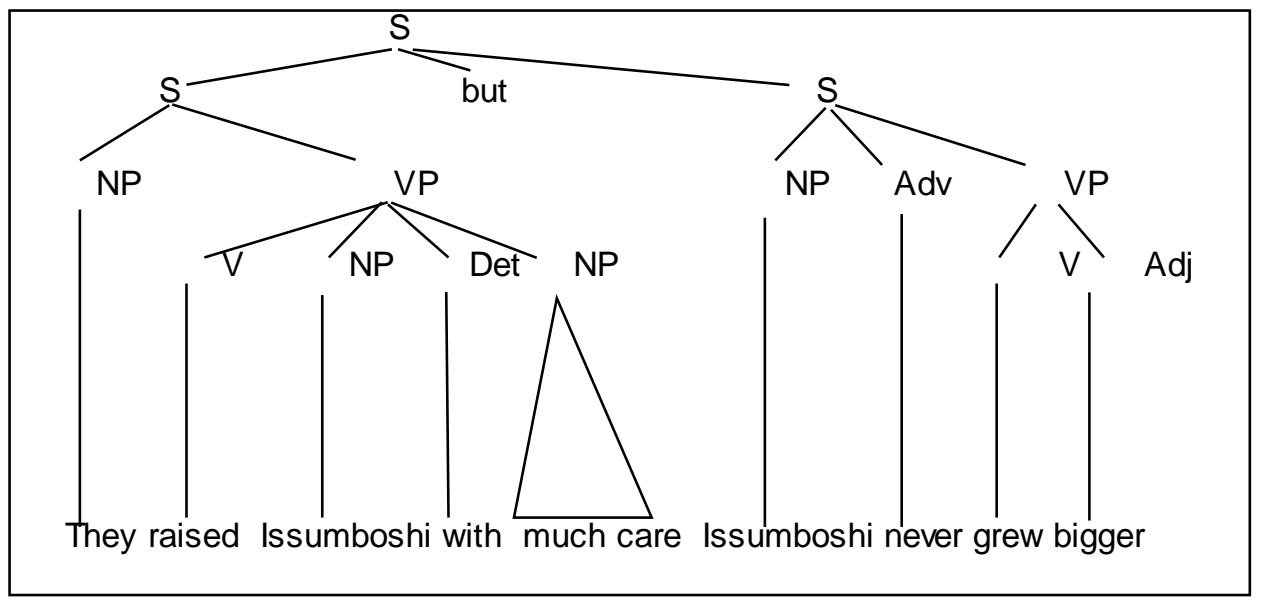

Chart 8. Tree diagram of a compound sentence

The demon rolled over and spat out Issumboshi. (page 159 line 49)

The compound sentence above consists of two independent clauses joined by the conjunction "and".

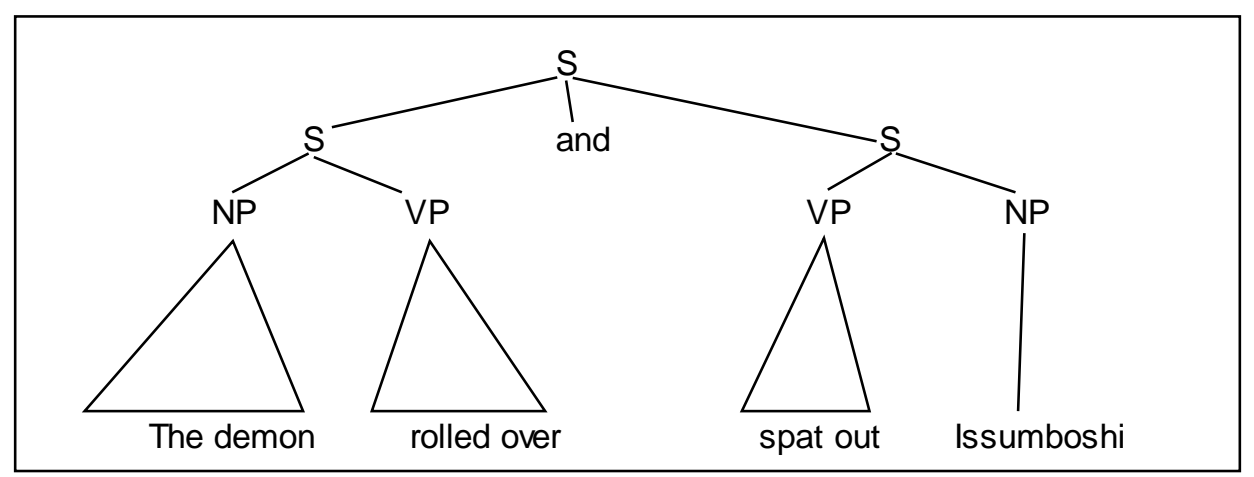

Chart 9. Tree diagram of a compound sentence

Issumboshi jumped at the demon and stabbed his eyes. (page 159 line 50)

The compound sentence above consists of two independent clauses joined by the conjunction "and".

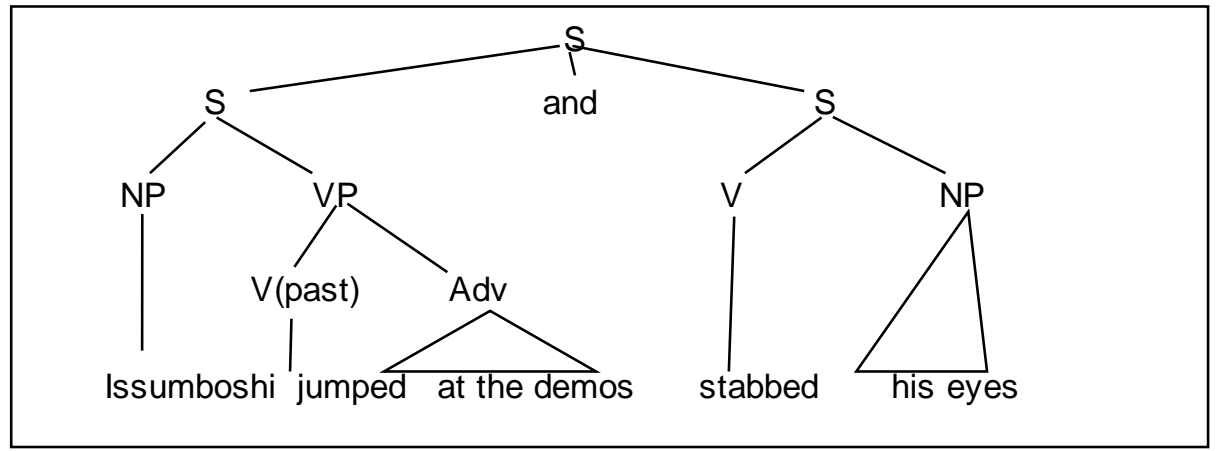

Chart 10. Tree diagram of a compound sentence

3. Complex Sentence

There are 33 sentences found in text 1 to 6 in the textbook, the writer took 5 complex sentences because some complex sentence has the same structure. The sentence structure of complex sentence such as:

$\mathrm{S} \Rightarrow \mathrm{S}+\mathrm{S}, \mathrm{S} \rightarrow \mathrm{NP}+\mathrm{VP}, \mathrm{S} \longrightarrow \mathrm{NP}, \mathrm{S} \rightarrow \mathrm{AdVP}+\mathrm{NP}$ 
A Syntactic Analysis on Sentences Found in the English Textbook for the Tenth Grade Students

Entitled "Bahasa Inggris Kelas X" (2017 revised edition) Published by Ministry of Education and

Culture Republic of Indonesia

Liana Mumrikoh', Eka Agustina², and Hastuti Retno Kuspiyah ${ }^{3}$

The structure above was indicating as a complex sentence because it has two sentences, one sentence as an independent clause and one sentence as a dependent clause. Furthermore, the tree diagram of complex sentences as follows:

The bloody took place because Indonesians refused to surrender their weaponry to the IC DC

British army. (page 123 line 3-5)

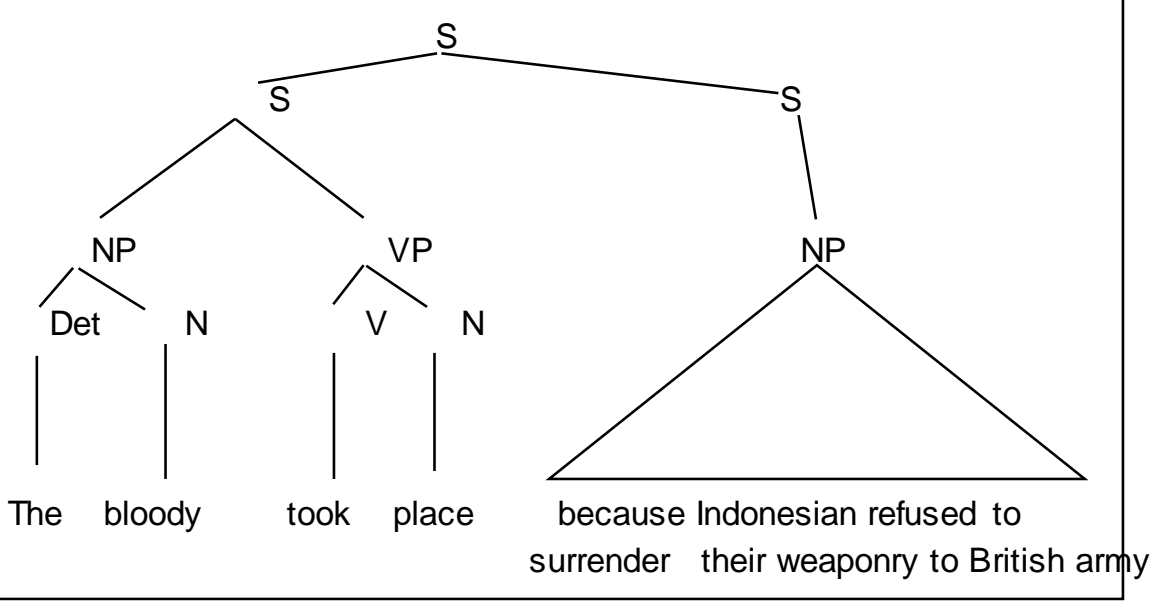

Chart 11. Tree diagram of complex sentence

total, between 6.000 and 16.000 Indonesians died while

IC

casualties on the British side were about 600 to 2000. (page 124 line 28)

DC

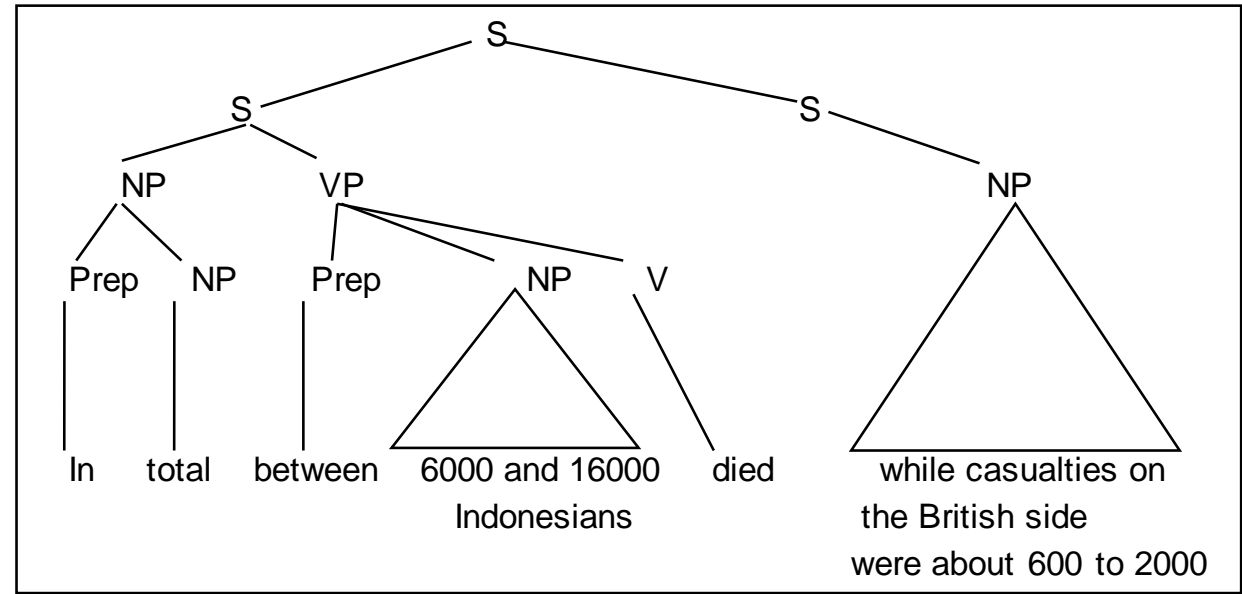

Chart 12. Tree diagram of complex sentence

Habibie worked on two projects which received funding from Deutsche Bundesbahn.

IC

DC

(page 135 line 28). 


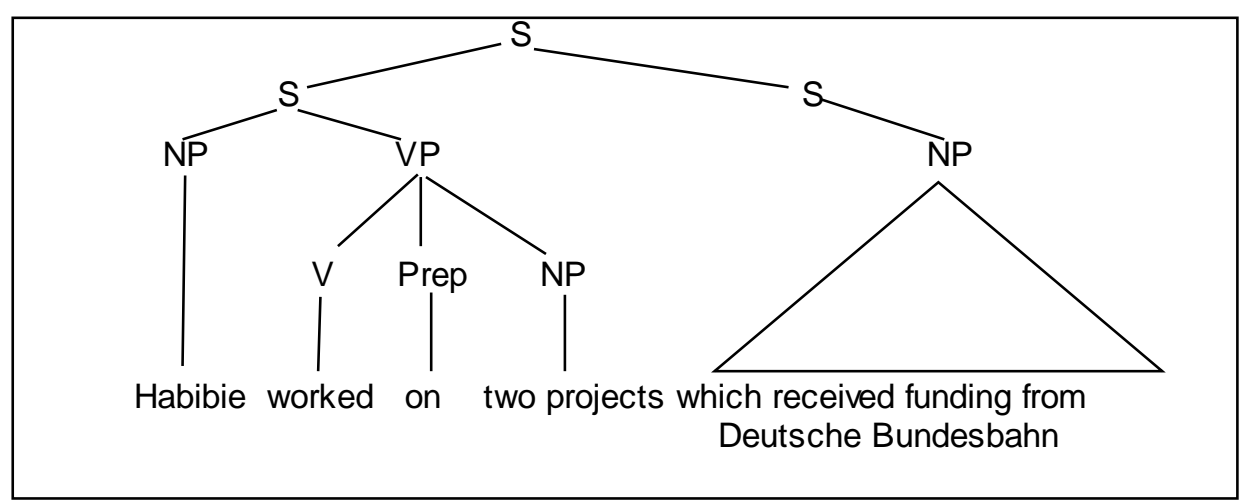

Chart 13. Tree diagram of complex sentence

Once upon a time, there was an old couple who didn't have a child. (page 157 line 1-2).

IC DC

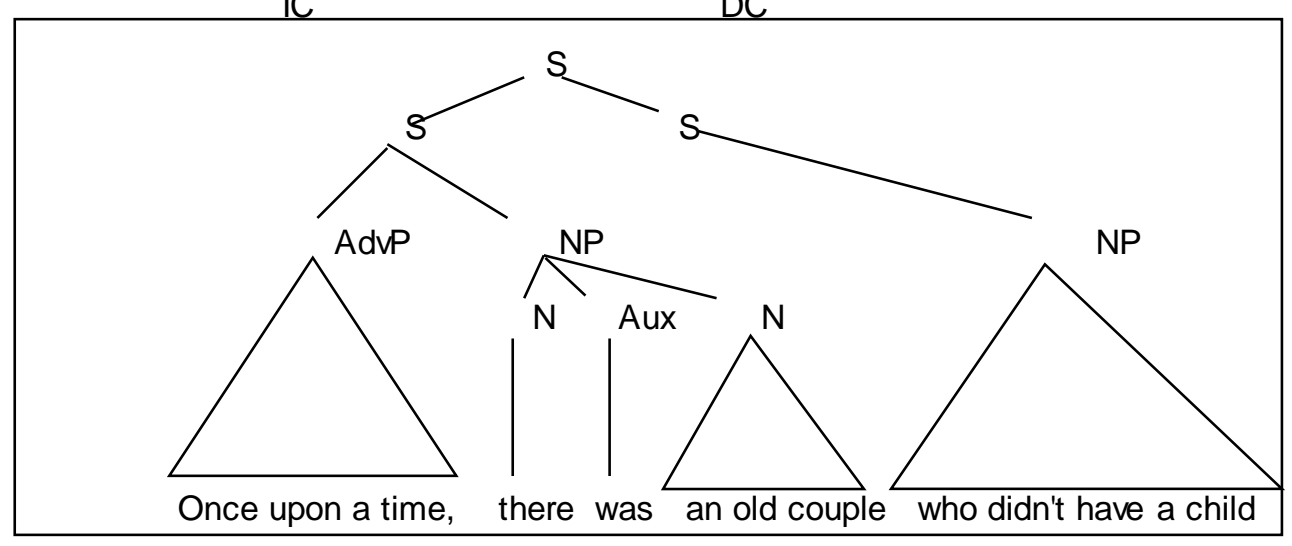

Chart 14. Tree diagram of complex sentence

The local people recognized that it was Malin Kundang, a boy from the area.

IC

DC

(page 172 line 14-15).

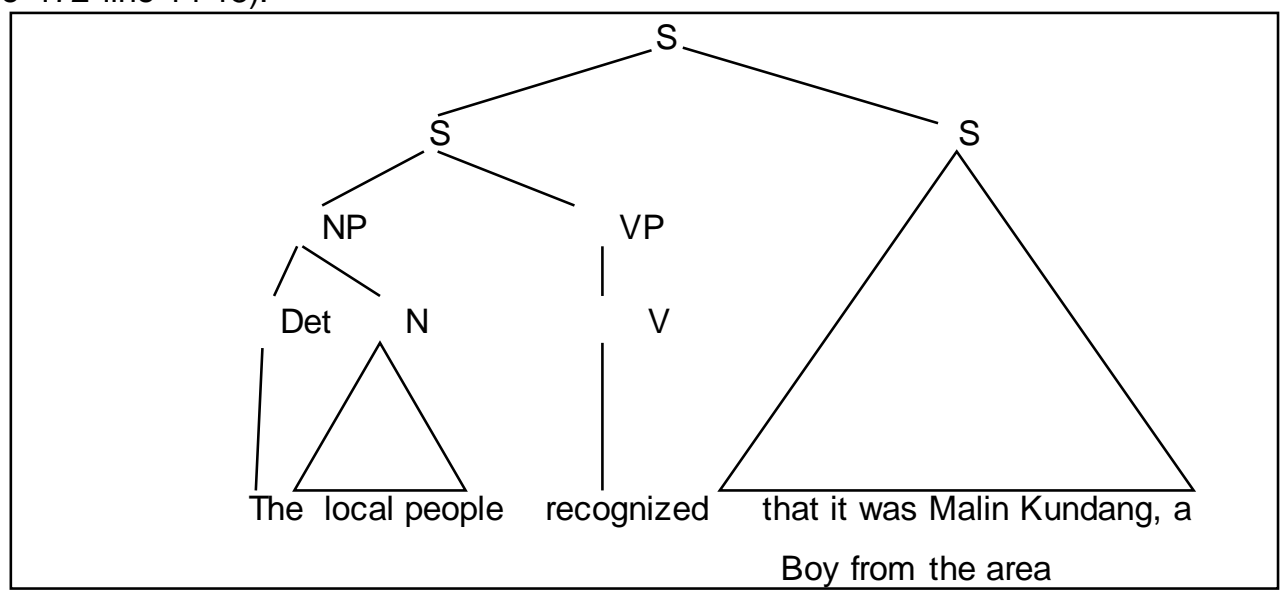

Chart 15. Tree diagram of complex sentence

4. Compound-Complex Sentence

There are 26 sentences found in text 1 to 6 in the textbook, the writer took 5 compoundcomplex sentences because some of the compound-complex sentences have the same structure. The sentence structure of compound-complex sentence such as:

$\mathrm{S} \longrightarrow \mathrm{S}+\mathrm{S}+\mathrm{S}, \mathrm{S} \longrightarrow \mathrm{NP}+\mathrm{VP}, \mathrm{S} \longrightarrow \mathrm{NP}, \mathrm{S} \longrightarrow \mathrm{AdvP}+\mathrm{NP}$, 
A Syntactic Analysis on Sentences Found in the English Textbook for the Tenth Grade Students

Entitled "Bahasa Inggris Kelas X" (2017 revised edition) Published by Ministry of Education and

Culture Republic of Indonesia

Liana Mumrikoh', Eka Agustina², and Hastuti Retno Kuspiyah ${ }^{3}$

$$
\mathrm{S} \rightarrow \mathrm{NP}+\mathrm{Aux}+\mathrm{Adv}, \mathrm{S} \rightarrow \mathrm{Adv}+\mathrm{NP}+\mathrm{Adj}
$$

The structure above was indicating as a compound-complex sentence because it has consisted of three sentences, one sentence as an independent clause and two sentences as a dependent clause. Meanwhile, the tree diagram of the compound-complex sentence as follows

I had always been thinking of how I would feel when I met him. (page 110 line 2-3)

IC

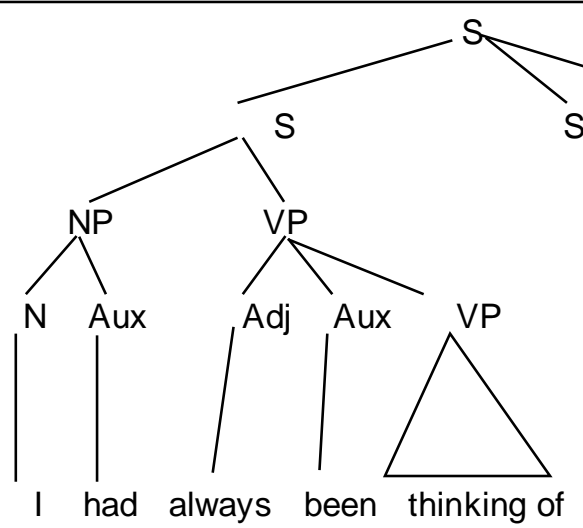

Chart 16. Tree diagram of a compound-complex sentence

DC DC

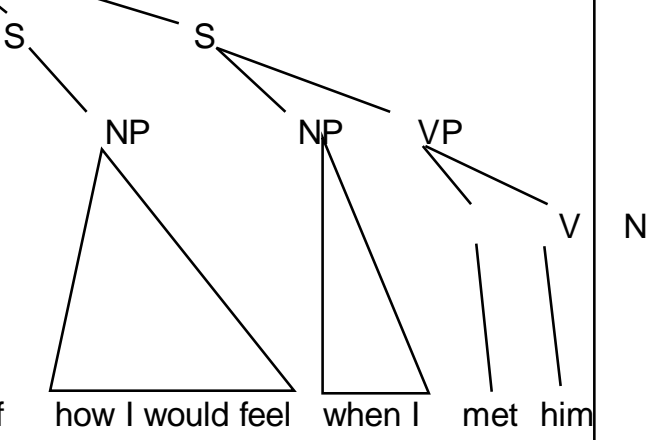

He was also friendly, so I didn't feel nervous when I had a chance to take pictures with him. IC DC DC

(page 111 line 32-33)

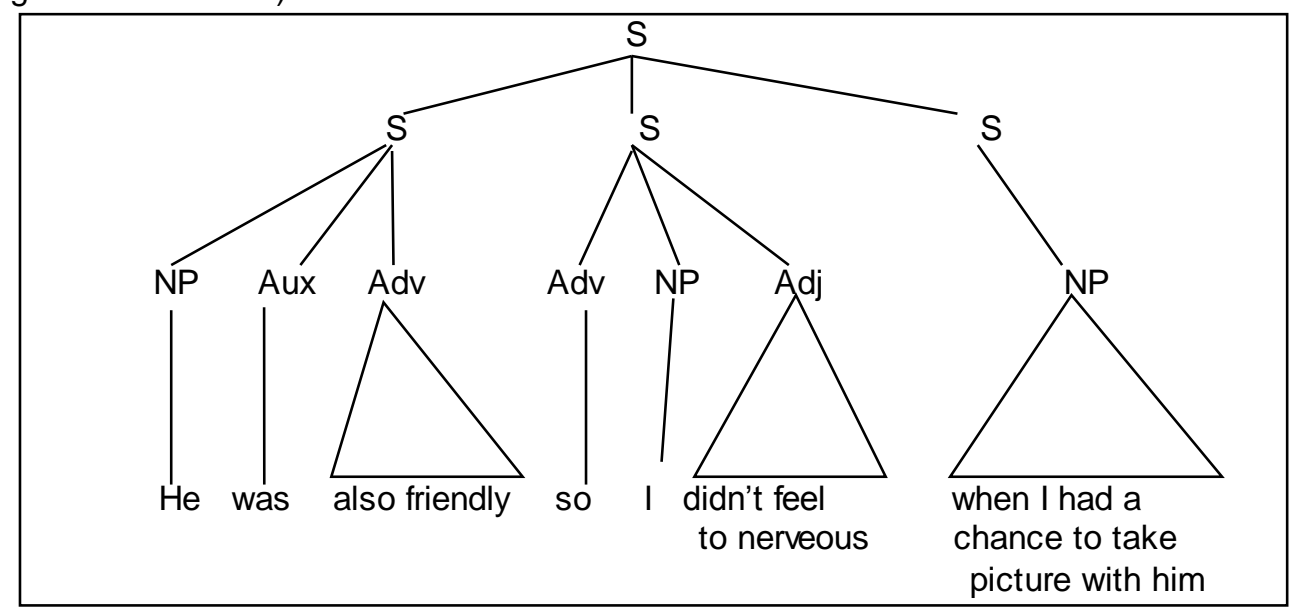

Chart 17. Tree diagram of a compound-complex sentence 
He had a huge ship and a lot of crews who worked loading trading goods.

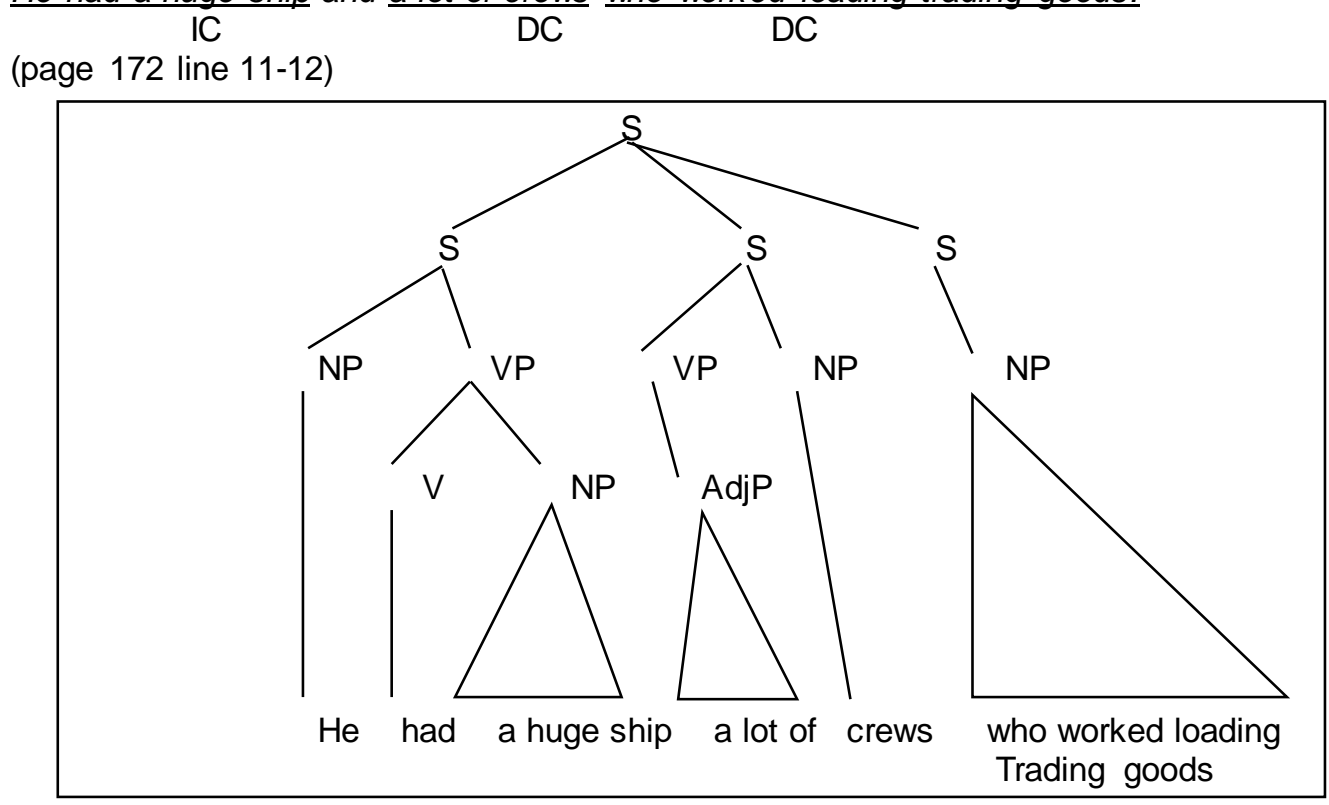

Chart 18. Tree diagram of a compound-complex sentence

She had pleaded Malin Kundang to look at her and admit that she was her mother.

IC

(page 172 line 20-21)
DC

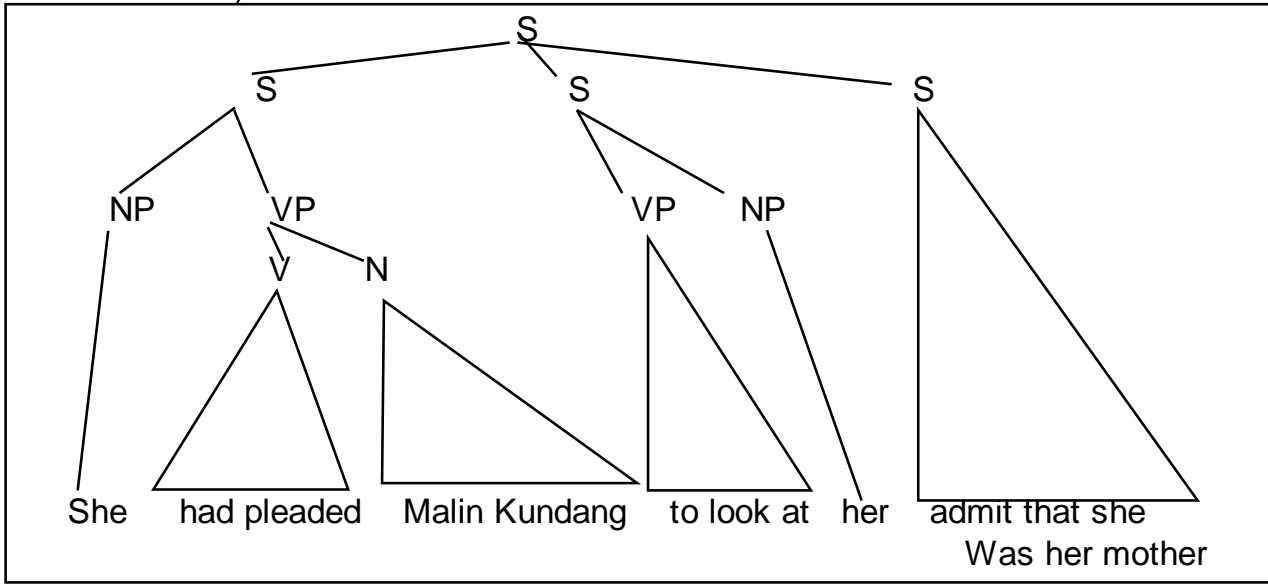

Chart 19. Tree diagram of a compound-complex sentence

From the result of finding and discussing on the syntactic analysis, the writer knew the structure of the sentence in the syntactic analysis that portrayed by a tree diagram. A tree diagram is a way of analyzing the sentence by using the internal hierarchical structure of the sentence as generated by a set of rules. be As we know, sentence structure rules generate structures. Also, the list of symbol and abbreviations in the syntactic analysis as follows:
S sentence
NP noun phrase
$\mathbf{N}$ noun
VP verb phrase
Adv adverb
V verb
Adj adjective
Prep preposition
Pro pronoun
PP prepositional phrases 


\section{CONCLUSION}

Concern to findings and discussions above, the writer concluded that the result of analyzing the textbook, as follows:

First, it can be inferred that the English textbook "Bahasa Inggris Kelas $X$ (2017 revised edition)" has all types of sentences, both types of sentences according to several clauses and types of sentences according to their syntactic properties. The text using a variety of sentence types to make it more interesting for the students, such as simple sentences, compound sentences, complex sentences, and compound-complex sentences.

Second, according to several clauses, the most occurred sentence type has 191 sentences, such as the first is a simple sentence; it is $27,75 \%$ or 53 sentences from the total number of the data. Second, compound sentence; it is $41,36 \%$ or 79 sentences from the total number of the data. Third, complex sentence; it is $17,27 \%$ or 33 sentences. The last is a compound-complex sentence; it is $13,61 \%$ or 26 sentences from the total number of the data.

Third, drawing tree diagram is the fundamental skill in the study of syntactic structure; it is a common practice to provide a visual representation of the internal structure of phrase and clause. Tree diagrams are a very clear way of representing syntactic structure graphically.

\section{REFERENCIES}

Christianto, Danin. (2018). Syntactic analysis of sentence patterns in John Denver's song lyrics. Thesis. Yogyakarta: Sanata Dharma University.

Comsky, Noam. (2002). Syntactic structures. Berlin: Mouton de Gruyter.

Grave, K. (2000). Designing a language course: a guide for teachers. Boston: Heinle \& Heinle.

Hendrawanto, Yusuf., \& Mulyani. (2017). Kelayakan Kebangsaan dan isi buku teks bahasa indonesia kelas xii semester 1 SMA. Semarang: Journal of Indonesian Language and Literature Study Program, Vol. 3, No. 2

Miller, Jim. (2002). An introduction to English syntax. Edinburgh: Edinburgh University Press Ltd.

Minister of Education. (2008). Panduan Pengembangan Bahan Ajar. Unpublished Copyright. Jakarta: National Education of Departement.

Oxford University Press. (2003). Oxford learner's pocket dictionary. Third Edition. Oxford: Oxford University Press.

Radford, Andrew. (2004). An introduction to English sentence structure. New York: Cambridge University Press.

Soeparno. (2002). Dasar-dasar linguistik umum. Yogyakarta: Tiara Wacana Yogya.

Suci, Isnia Wulan. (2014). Syntactic analysis on the headlines in new york times in the first two weeks Of May 2014 (1 st $^{\text {to }} 14^{\text {th }}$ of May). Thesis. Tulungagung: English Education Program Faculty Of Islamic Education State Islamic Institute (lain) Tulungagung.

Vespoor, M., \& Sauter, K. (2002). English sentence analysis. Amsterdam: John Benjamins Publishing Company.

Widiati, Utami., dkk. (2017). Bahasa inggris kelas x. Jakarta: Ministry of Education and Culture Republic of Indonesia. 